Article details

Article title: Edmund Allenby

Article ID: $9780199791279-0160$

Article author(s): Matthew Hughes and lain Farquharson

Publishing Group: Reference-US

$\square$ Revision (XML provided)

Title revised? $\mathrm{Y} / \mathrm{N}$

Previous title:

Table of contents:

Introduction

Biographical Accounts

British Strategy in the First World War

Official British Histories of Allenby's

Campaigns

Imperial and Turkish Official

Histories

Belgium and France, 1914-1917

Palestine

Contemporary Accounts

Unit and Campaign Histories

More Recent Scholarship

The Imperial Perspective

Lawrence and the Hashemites

Egypt

Style and XML details

Citation style: Humanities

Special characters/fonts/elements:

Module details

Module: Military History

Module code: MIL

Module ISBN: 9780199791279

Format neutral

Note: All content will be format neutral compliant, unless otherwise indicated here Exceptions:

- Oxford Bibliographies articles do not currently have keywords. Introductions serve as abstracts. 


\section{EDMUND ALLENBY}

\section{Introduction}

General Sir Edmund Allenby (later, Field Marshal and Viscount, 1861-1936) served in South Africa and Bechuanaland (Botswana), passed Staff College, fought in the Boer War (18991902), became Inspector General of Cavalry, and then assumed command of the Cavalry Division on the outbreak of the First World War. The war divided into two uneven halves for Allenby, the longer (and less successful) first part spent in France and the final (more successful) one in command in Palestine. Allenby led the difficult cavalry retreat from Mons in Belgium in 1914, went on to corps and army command on the Western Front, culminating with command of Third Army at the Battle of Arras in April-May 1917, the only major offensive of Allenby's in France. The Arras attack bogged down after some initial success, casualties mounted, and subordinate commanders at the time and historians subsequently criticized Allenby for his failure to challenge orders from his overall commander in France, Sir Douglas Haig, to prolong the offensive. Needing a new commander for the Egyptian Expeditionary Force in Palestine, the British Prime Minister, David Lloyd George, dispatched Allenby to Egypt to take command in June 1917 against the Ottomans (Turkey). Allenby made his name in Palestine. He rebuilt the Egyptian Expeditionary Force, established up-to-date Western Front standards of operations, and restored the force's confidence and morale. London also sent him substantial reinforcements. The Egyptian Expeditionary Force won the Third Battle of Gaza (November-December 1917), conquering southern Palestine and capturing Jerusalem in December 1917. In Palestine, Allenby worked with the Arab Hashemite army under the command of Prince Feisal fighting on his right flank across the River Jordan. T. E. Lawrence-_Lawrence of Arabia"—was Britain's liaison officer with the Hashemite forces. Allenby's forces at the final Battle of Megiddo (September-October 1918) crushed Turkish forces in Palestine and swept forward to occupy all of what would become Transjordan, Syria, and Lebanon. Allenby supported the Hashemites, allowing them to enter Damascus first and so helping to establish British political influence in the region. London then appointed Allenby high commissioner in Egypt, a post he held during the Egyptian independence revolution. While there are four biographies of Allenby and several essays directly assessing his command and character, much of our understanding of Allenby is embedded in the official and unofficial histories of Allenby's military campaigns in Belgium and France (1914-1917) and in Palestine (19171918). Accounts and diaries of and by figures such as T. E. Lawrence, Ronald Storrs (military and then civil governor of Jerusalem) and Richard Meinertzhagen (British army intelligence officer) also touch on Allenby, as do studies of British strategy in the First World War and political histories of the postwar peace settlement that formed the modern Middle East.

\section{Biographical Accounts}

Biographies of Allenby begin with Savage 1925 and Wavell 1940_-both served under Allenby - through Gardner 1965 and James 1993, ending with comparative command assessments by Urban 2006 and Black 2011. C S. Forester 1936 is a fictional account of a general of this period, a composite character based in some measure on Allenby. Hughes 2006 (cited under *Belgium and France, 1914-1917*) provides a good overall summary of Allenby's character and his role in operations on the Western Front.

Black, Jeremy. "Edmund Allenby." In The Art of War. Great Commanders of the Modern

World. Edited by Andrew Roberts, 268-275. London: Quercus, 2009. [ISBN:

9781847242600] 
Edited by Roberts, the coverage of fifty commanders of the modern period in this volume includes Jeremy Black's short (three thousand word) assessment of Allenby, a concise, quick read covering the main elements of Allenby's military skills.

Forester, C. S. The General. London: Michael Joseph, 1936.

Forester's sympathetic portrayal of a general of the era is an easy read and acts as a rebuttal to the idea that all British generals of the First World War were hidebound, unthinking "Colonel Blimps." Forester shows how commanders struggled to control the modern, industrial battlefield. Forester, who wrote widely, including the Hornblower naval series of fiction books, brings his subject to life.

Gardner, Brian. Allenby. London: Cassell, 1965.

Gardner used Allenby's papers for the first biography by an author who had not served under Allenby. A readable and scholarly account of Allenby's whole life that tackles the issue of whether he was a martinet. It partially covers the issues of whether Allenby bungled the cavalry retreat from Mons, failed in France, and succeeded in Palestine because he deployed overwhelming force against his enemy.

James, Lawrence. Imperial Warrior: The Life and Times of Field Marshall Viscount Allenby 1861-1936. London: Weidenfeld and Nicolson, 1993. [ISBN: 9780297811527]

Making use of the Allenby papers, James is the most recent critical biography of Allenby that provides a balanced, readable assessment of the life and times of Allenby. James gives examples of Allenby's notorious temper when dealing with subordinates in France during the First World War. He also tackles the issue of whether Allenby was out of his depth in command in France and whether he failed at the Battle of Arras.

Savage, Raymond. Allenby of Armageddon. London: Hodder and Stoughton, 1925.

This is the first biography of Allenby, one written by an officer who served under Allenby, and, while it is an interesting read, it is hagiographical of its subject and does not make use of Allenby's papers. Lacks detailed footnotes.

Urban, Mark. Generals: Ten British Commanders Who Changed the World. London: Faber and Faber, 2006.

Urban describes and weighs up the military lives of ten British generals from Monck to Montgomery, written in a lively, engaging style and provides succinct analysis of Allenby as one of the great generals of history.

Wavell, Archibald. Allenby: A Study in Greatness: The Biography of Field Marshal Viscount Allenby of Megiddo and Felixstowe. London: Harrap, 1940.

Wavell served under Allenby in Palestine and wrote an account of the Palestine campaign in 1929 (cited in Unit and Campaign Histories). Wavell went on to high-level command in the Second World War, which was when he wrote his two-volume biography of Allenby. Lady Allenby gave Wavell access to Allenby's papers (this is apparent when one consults the Allenby papers held at King's College London in which Wavell has left his notes on his biography), and Wavell brings to his subject a real understanding of the battlefield. The footnoting to both volumes is exiguous.

Wavell, Archibald. Allenby in Egypt: Being Volume II of Allenby: A Study in Greatness. London: Harrap, 1943.

The second volume on Allenby's time as high commissioner in Egypt is much shorter. The "greatness" in Wavell's title is a reference to Allenby's correct behavior in the face of scheming against him by junior and senior officers when he was in France. There are reprints of both of these hard-to-get Wavell volumes (London: Gregg Revival, 1992).

\section{British Strategy in the First World War}

French 1995, Hughes 1999, and Woodward 2004 explicitly connect Allenby's command in Palestine to wider British strategy. These works contextualize Allenby's commands in France 
and Palestine within broader British strategy. The issue of Allenby and British strategy is also discussed in the literature cited under *More Recent Scholarship*. Ulrichsen 2010 and Ulrichsen 2014 add insight into the logistical, social and economic influences on Allenby's campaigns.

French, David. The Strategy of the Lloyd George Coalition, 1916-1918. Oxford: Oxford University Press, 1995. [ISBN: 9780198205593]

Well researched, scholarly account laying out the key issues surrounding British strategy in the last two years of the war and the clash between those who wanted Britain to focus on the war in France and those who wanted to reinforce peripheral war zones such as Palestine. Richly footnoted and informed.

Hughes, Matthew. Allenby and British Strategy in the Middle East, 1917-1919. London: Cass, 1999. [ISBN: 9780714649207]

Focuses directly on Allenby in Palestine, showing how the Palestine campaign was wrapped up in wider squabbles in the British high command about how best to direct and manage Britain's power in the war. The book also assesses the operational level of war in Palestine and provides an overall assessment of the Palestine campaign, in both military and political terms.

Hughes, Matthew, ed. Allenby in Palestine. London: Army Records Society, 2004.

This edited collection of key documents such as letters and memoranda from Allenby's period in charge in Palestine (and Egypt after the war) includes a long introduction that concisely details Allenby's key strategy decisions and how he liaised with London on the strategy of the Palestine campaign.

Ulrichsen, Kristian Coates. The Logistics and Politics of the British Campaign in the Middle East, 1914-22. Basingstoke, UK: Palgrave-Macmillan, 2010. [ISBN: 9780230233003] This is an interesting study of the central role of logistics and supplies in Allenby's campaign in Palestine which argues that the huge demand for supplies for Allenby's army across the British Empire led to more authoritarian imperial rule.

Ulrichsen, Kristian Coates. The First World War in the Middle East. London: Hurst, 2014. [ISBN: 9781849042741]

A good, up-to-date overview of all the campaigns in the Middle East, including Allenby's in Palestine, covering military, social, and economic aspects of the war.

Woodward, David. Lloyd George and the Generals. London: Frank Cass, 2004. [ISBN: 9780203010136]

Woodward dissects the dispute between Britain's military and political leaders - notably the prime minister, David Lloyd George, and the senior military commander, General Sir William Robertson - over the course of the war. An effective summary of all the key issues. Originally published 1983 (Newark: University of Delaware Press).

\section{Official British Histories of Allenby's Campaigns}

Falls 1940 and Falls 1928-1930 are the official British war histories of Allenby's campaigns in France and Palestine and include rich contemporaneous detail on the battles fought by Allenby. Only the salient British volume for France, covering the Battle of Arras (Falls 1940) is cited (there are almost thirty British volumes in total); all the volumes for Palestine are cited. Jones 1922-1927 covers the experiences of the air element, with Macpherson 19211924 providing the official history of the army medical services. Pirie-Gordon 1919 meanwhile provides a useful factual supplement to other official histories of the period. Readers should be aware that Germany (Der Weltkrieg 1914-1918: Bearbeitet im Reichsarchiv. Berlin: Mittler and Sohn, 1925-1930) and France (Les Armées Françaises dans la Grande Guerre. Paris: Imprimerie Nationale, 1922-1937) also produced multivolume official histories of the war on the Western Front. 
Falls, Cyril. Official History of the War: Military Operations: France and Belgium 1917.

Vol. 1. London: Macmillan, 1940.

This volume covers the battle of Arras and is a rich text, long on military detail. It provides the facts and narrative for the Battle of Arras and includes information on the decisions made by Allenby and also those made by the Germans, as the official historians interviewed German officers involved in the battles, and includes their views in the official histories. The text of the official histories is more critical than might be apparent from a brief read in which criticism of failed operations can seem muted.

Falls, Cyril, and George Macmunn. History of the Great War, Military Operations, Egypt and Palestine. 2 vols. London: HMSO, 1928-1930.

Macmunn's name appears on volume one of the Palestine campaign official history, but Falls wrote the text. The second volume, itself divided into two parts, deals with Allenby's command after June 1917. The Palestine British official history is an essential starting point for any understanding of Allenby's military operations. Good coverage, too, of the German units that fought with the Turks against Allenby. Excellent color maps of the campaign, which appear in black and white in the 1996 reprints of these histories (Nashville: Battery). Jones, H. A., with Walter Raleigh. History of the Great War Based on Official Documents: The War in the Air: Being the Story of the Part Played in the Great War by the Royal Air Force. 6 vols. Oxford: Clarendon, 1922-1937.

Allenby's augmented air force helped him with reconnaissance, mapping, and gaining air superiority over Palestine against hitherto superior German-supplied warplanes on the Turkish side. Volume 5 of the official history of the war in the air covers Palestine.

Macpherson, William G. Medical Services: General History, History of the Great War Based on Official Documents. 4 vols. London: HMSO, 1921-1924.

The multivolume official history of Britain's medical services in the First World War examines Palestine and not just the extensive work done with wounded soldiers but also the key areas of disease prevention and cure, including tackling the chronic problem of venereal disease.

Pirie-Gordon, H. A Brief Record of the Advance of the Egyptian Expeditionary Force under the Command of General Sir Edmund H. H. Allenby-July 1917 to October 1918. London: HMSO, 1919.

Compiled from official sources and published by the Government Press and Survey of Egypt, this is an official record of the advance of Allenby's troops and a useful supplement to the official histories listed in this section. Good for facts and detail rather than opinion.

\section{Imperial Official Histories and Histories of the Turkish Army}

Australia and New Zealand produced official histories of the theaters of war where their troops fought, such as in Palestine. These volumes provide alternative viewpoints, often more critical, on Allenby's generalship. Guy Powles's The New Zealanders in Sinai and Palestine provides in-depth analysis of the Transjordan raids of early 1918 (Powles 1922). The Turkish military also wrote multivolume histories of the war in the Middle East, best summarized by Erickson 2001 and Erickson 2007 as the original Turkish volumes are not only hard to obtain but are written (especially those completed just after the First World War) in a form of Turkish that is difficult to read. Erickson's volumes are not official histories but are included here as they open a window on to the much-neglected Turkish side of Allenby's war in Palestine.

Erickson, Edward. Ordered to Die: A History of the Ottoman Army in the First World War. London: Greenwood, 2001. [ISBN: 9780313315169]

A useful military analysis in English of the war in the Middle East from the perspective of the Turks, based on the Turkish official histories. It does not deal explicitly with Allenby 
but it includes an examination of operations in Palestine. Strong military focus. Not an official history but worth consulting for the Turkish side of the war.

Erickson, Edward. Ottoman Army Effectiveness in World War I: A Comparative Study.

London: Routledge, 2007. [ISBN: 9780415770996]

This examination of Turkish forces is a useful coda to Erickson 2001 and argues

sympathetically that Ottoman forces were combat effective but suffered from a general lack of effective logistics and support. It compares Turkish and British-led forces.

Gullett, H. S. The Official History of Australia in the War of 1914-1918. Vol. 7, Sinai and Palestine, The Australian Imperial Force in Sinai and Palestine, 1914-1918. St Lucia: University of Queensland Press, 1984.

Gullet's official history of Australia's part in the war in Palestine is readable and critical in tone when set alongside the British official history. Its focus is on the Australian mounted infantry (the Australian Light Horse) that served under Allenby. The volume covers the campaign and Allenby's impact as commander. The Australians filled the ranks of two of Allenby's three mounted divisions in late 1917 and were pivotal for mobile operations. Originally published in 1923, reprinted in 1984. Good maps that appear in color in the 1984 edition.

Powles, C. Guy. The New Zealanders in Sinai and Palestine, Volume III of the Official History of New Zealand's Effort in the Great War. Auckland, New Zealand: Whitcombe and Tombs, 1922.

New Zealand contributed one mounted infantry brigade to the Egyptian Expeditionary Force, and this postwar official history volume tells the narrative story of their actions in Palestine. Useful for its coverage of the fiasco at the Transjordan raids early in 1918, when Turkish forces repulsed Allenby's attack into Jordan directed at Amman.

\section{Belgium and France, 1914-1917}

Gardner 1999 and Gardner 2003 cover Allenby's time on the Western Front in command of the Cavalry Division. Questions were raised about Allenby's handling of the oversized (fourbrigade) Cavalry Division in 1914 during the retreat from Mons - the division effectively fell apart with some brigade commanders acting independently. Haldane 1948, Hughes 2006, Simkins 1999, and Nicholls 1993 examine Allenby's extension of the Battle of Arras in April-May 1917. Even Allenby's obituary in The Times on 15 May 1936 remarked on how he "conscientiously, if clumsily" prolonged operations at Arras. The problem was not just the awful nature of the war in France that made a breakthrough impossible but also Allenby's tense, obedient relationship with Haig, one that, arguably, made him reluctant to tell Haig that he needed to terminate the attack at Arras. Hughes 2006 shows that the fighting at Arras was so futile that three of his divisional commanders protested in what was, in effect, a generals' mutiny. The successes of the Palestine campaign have obscured Allenby's problematic period in command in France.

Gardner, Nikolas. "Command and Control in the 'Great Retreat' of 1914: The Disintegration of the British Cavalry Division.” Journal of Military History 63 (January 1999): 29-54.

This article provides a good summary of Allenby's role in the first few months of the war in charge of the Cavalry Division, and it examines and assesses the charge that Allenby lost control of the division in the British retreat from Belgium at the start of the First World War.

Gardner, Nikolas. Trial by Fire: Command and the British Expeditionary Force in 1914. Westport, CT: Praeger, 2003. [ISBN: 9780313324734]

An academic, book-length study of the opening months of the war for the British in Belgium and France, in which Allenby took part while in charge of the British cavalry force. 
Haldane, Aylmer. A Soldier's Saga: The Autobiography. Edinburgh, UK: Blackwood, 1948. Haldane was one of Allenby's corps commanders. His account of his time serving under Allenby in Third Army is insightful, if generally hostile toward and critical of Allenby. This is an interesting, personal account.

Hughes, Matthew. "General Allenby." In Haig's Generals. Edited by Ian Beckett and Steven Corvi, 12-32. Barnsley, UK: Pen and Sword, 2006. [ISBN: 9781844151691]

Beckett and Corvi's edited volume covers all of Haig's army commanders, including a chapter by Hughes on Allenby. Hughes not only assesses Allenby's command at Arras, but he also dissects Allenby's character and the charge that he was overly critical of subordinates and had an explosive, unpleasant temperament. Incudes amusing quotations detailing Allenby's loss of temper with subordinates. The exploration of Allenby's character here helps draw a fuller picture of his troubled time in command in France.

Neillands, Robin. The Great War Generals on the Western Front. London: Robinson, 1998. [ISBN: 9781854879004]

Readable comparative assessment of senior generals on the Western Front, including Allenby.

Nicholls, Jonathan. Cheerful Sacrifice: The Battle of Arras, 1917. Barnsley, UK: Leo Cooper, 1993. [ISBN: 9780850525205]

One of the few books dealing specifically with the Battle of Arras, Allenby's one major battle in France in the First World War.

Sheffield, Gary. Forgotten Victory. London: Headline, 2001. [ISBN: 9780747271574] An examination that reassesses the British army and generals of the First World War sympathetically, showing how they overcame considerable difficulties to defeat Germany, a victory that has been largely forgotten after the war. Touches on Allenby and Arras and provides a revisionist perspective on the war.

Simkins, Peter. "Haig and His Army Commanders." In Haig: A Reappraisal 70 Years On. Edited by Brian Bond and Nigel Cave, 78-106. Barnsley, UK: Leo Cooper, 1999. [ISBN: 9780850526981]

Simkins provides a well-informed chapter in Bond and Cave's volume reappraising Haig that covers Allenby and his awkward relationship with Haig.

\section{Palestine}

Some of the official histories of the Palestine campaign are cited under other section headings; this section examines key texts written by those who fought with and against Allenby in Palestine, alongside a description of some later studies of the war in the region.

\section{Contemporary Accounts}

After the war, there were official and semi-official "in-house" unit histories from corps down to regimental level, often written by former officers in those units such as Bluett 1919, Wheeler 1935, and Gilbert 1923, personal memoirs such as Storrs 1937, Meinertzhagen 1959, and Meinertzhagen 1960 as well as reportage of the campaign by Thomas and Collings 1938 written just after the event. All of the books mention Allenby, usually in uncritical terms, the victory in Palestine fresh in people's minds and a romantic contrast to the attritional slog of the war on the Western Front. The tone of many of these volumes is celebratory, presenting Allenby's war as a "crusade."

Bey, Skander. "The Battles of Salt, Aman [sic] and Jordan from Turkish Sources." Journal of the Royal United Services Institute 69 (May 1924): 334-343.

A useful translation of material from the much-neglected Turkish side of operations, about which too little has been written, not least as source material is hard to find. The second 
part of this two-part essay is found in Journal of the Royal United Services Institute 69 (August 1924): 488-498.

Bluett, Antony. With Our Army in Palestine. London: Andrew Melrose, 1919.

Interesting, descriptive account from a gunner in the artillery serving in Allenby's army in Palestine of what it was like to fight in Sinai and Palestine, right up to the final rout of the Turkish armies in 1918.

Gilbert, Vivian. The Romance of the Last Crusade: With Allenby to Jerusalem. New York: D. Appleton, 1923.

Major Vivian Gilbert served in Palestine and was involved in the capture of Jerusalem in December 1917, an event recounted in his book on the campaign. Gilbert was in a brigade with London-based regiments.

Meinertzhagen, Richard. Middle East Diary, 1917-56. London: Cresset, 1959.

Meinertzhagen served as an intelligence officer on the Palestine front and was involved in deception operations in 1917 before the Third Battle of Gaza (what was known as the "haversack ruse") that supposedly fooled the Turks as to the direction of the attack. It has been said that Meinertzhagen's diaries have been doctored and his life embellished. Also see the second volume of his diaries: Army Diary, 1899-1926 (London: Oliver Boyd, 1960).

"The Surafend Incident: Why Allenby Ignored the Anzacs." New Zealand Returned Soldiers' Association Review 15 (February 1939): 17-18.

A short essay written by returning New Zealand soldiers giving their side of a controversial incident in Palestine at the military camp of Surafend after the war's end where Australian and New Zealand soldiers beat to death local Palestinians after the murder of a comrade. Allenby was shocked at the killings of the Palestinians and punished the Australian and New Zealand troops.

"The Surafend Incident, Further Light on Same." New Zealand Returned Soldiers' Association Review 15 (May 1939): 26-27.

The second part of the account by New Zealand soldiers of the Surafend incident.

Storrs, Ronald. Orientations. London: Nicholson and Watson, 1937.

Storrs served as military and then civil governor of Jerusalem from 1917 to 1926 and his memoir entitled Orientations gives a sense of the religious and political machinations surrounding Allenby's conduct of operations in the Holy Land.

Thomas, Lowell, and Kenneth Brown Collings. With Allenby in the Holy Land. London: Cassell, 1938.

Thomas was an American writer, broadcaster and traveler who went to Palestine as an official US foreign correspondent during the First World War and where he filmed T. E. Lawrence in the desert, turning his experiences into a successful film of his time in Palestine with which he toured the world.

Wheeler, George. "The Capture of Damascus in 1918." Cavalry Journal (July 1935): 44-48.

Short, contemporary account of the politically significant capture of Damascus in September-October 1918 when Allenby allowed Hashemite forces into the city first to help establish them in the city.

\section{Unit and Campaign Histories}

The unit and campaign histories cited here were all produced shortly after the war. These accounts, while not having access to the same official source material available to historians of more recent times (as well as to the authors of the official histories), provide valuable narrative and personal accounts of the campaign and they recount Allenby's generalship. Bowman-Manifold 1922, More 1923, and Preston 1921 provide the "soldier's eye" view of the campaign in Palestine as well as the experiences of individual units within Allenby's 
force, while Massey 1919, Massey 1920, Wavell 1922, and Wavell 1929, from Massey's and Wavell's position as an official war correspondent and a corps-level staff officer, respectively, examine the campaign's strategy.

Bowman-Manifold, M. G. E. An Outline of the Egyptian and Palestinian Campaigns. Chatham, UK: Mackay, 1922.

Bowman-Manifold (later major-general) was a senior officer in Palestine in charge of signals, and he provides a first-hand account of the campaign and Allenby's command.

Massey, W. T. How Jerusalem Was Won: Being the Record of Allenby's Campaign in Palestine. London: Constable, 1919.

Massey wrote three books on the Palestine campaign, the second two published in 1919 and 1920 are cited here as they relate directly to Allenby's period in charge in Palestine.

Massey, W. T. Allenby's Final Triumph. London: Constable, 1920.

The final book of Massey's trilogy on Allenby and the Palestine campaign, examining the period after the capture of Jerusalem to the Battle of Megiddo.

More, John N. With Allenby's Crusaders. London: Heath Cranton, 1923.

The author served as a subaltern with the British 53rd (Welsh) Division, and this account gives a good soldier's eye view of the war in Palestine in the last years of the war. The book is something of a divisional history.

Preston, R. M. P. The Desert Mounted Corps: An Account of the Cavalry Operations in Palestine and Syria, 1917-1918. London: Constable, 1921.

Lieutenant-Colonel Preston served in the artillery with the Australian Mounted Division in Palestine, and this first-hand account narrates the role of the three mounted divisions in Allenby's Desert Mounted Corps, starting in June 1917.

Wavell, Archibald. "The Strategy of the Campaigns of the Egyptian Expeditionary Force." Army Quarterly (3 January 1922): 235-249.

Wavell served in Palestine, and this essay covers the main strategic aspects of the campaign.

Wavell, Archibald. The Palestine Campaigns. London: Constable, 1929.

Readable, informed account of Allenby's war in Palestine. Wavell was a staff officer in

Palestine, ending the war as a brigadier general, general staff for XX Corps and so had an excellent insight into the conduct of operations in Palestine.

\section{More Recent Scholarship}

Anglesey 1994, Bruce 2002, Dolev 2007, Grainger 2006, Grainger 2013, Kinloch 2007, Newell 1991, Perret 2004, and Sheffy 1998 take advantage of the opening up of archivesespecially in Britain and Australia - that were not available to those who wrote first-hand accounts in the 1920s and 1930s. The scholarship here covers well-worn stories about the capture of Jerusalem and the final defeat of the Turkish armies at the war's end.

Anglesey, Marquess of. A History of the British Cavalry, 1816-1919. Vol. 5, Egypt, Palestine and Syria, 1914-1919. London: Leo Cooper, 1994. [ISBN: 9780850523959] In his fifth volume, Lord Anglesey recounts the exploits of the Australian and New Zealand "Light Horse" mounted infantry, the British mounted Yeomanry and (from Spring 1918) Indian cavalry in Palestine. He argues that the Light Horse of Australia and New Zealand were perhaps the most skillful mounted soldiers on horseback in British history.

Bruce, Anthony. The Last Crusade: The Palestine Campaign in the First World War. London: John Murray, 2002. [ISBN: 9780719554322]

An up-to-date, popular, informed, and readable account of Allenby's campaign in Palestine, provocatively picking up on the "crusader" epithet that had been given at the time to Allenby's capture of the Holy Land. 
Dolev, Eran. Allenby's Military Medicine: Life and Death in World War 1 Palestine. New York: I. B Tauris, 2007. [ISBN: 9781845112905]

An interesting specialist study by an Israeli military doctor of Allenby's medical services, showing how important medicine (and disease prevention) was to Allenby's eventual success. The study shows how support services and logistics were just as important for winning Allenby's campaign as were fighting forces.

Grainger, John. The Battle for Palestine 1917. Woodbridge, UK: Boydell, 2006. [ISBN: 9781843832638]

The first of two books by Grainger covering the Palestine campaign, this one examining the penultimate year of the war and includes detail on Allenby's role in leading operations.

Grainger, John. The Battle for Syria, 1918-20. Woodbridge, UK: Boydell, 2013. [ISBN: 9781843838036]

Grainger's second volume on the Palestine campaign examines not only Allenby's final defeat of enemy forces in Palestine but the significant political machinations surrounding control of captured enemy territory, notably the claims by Arab (Hashemite) forces and France for control of part or all of the region. There was also the question of Zionist (Jewish nationalist) demands to extend Jewish settlements in Palestine.

Kinloch, Terry. Devils on Horses: In the Words of the Anzacs in the Middle East, 1916-19. Auckland, New Zealand: Exisle, 2007. [ISBN: 9780908988945]

An account of the antipodean soldiers' time in Sinai and Palestine using their original letters and diaries to reconstruct their experience of the fighting and of the desert campaign.

Newell, Jonathan. "Allenby and the Palestine Campaign." In The First World War and British Military History. Edited by Brian Bond, 189-226. Oxford: Clarendon, 1991. [ISBN: 9780198222996]

An interesting, revisionist assessment of Allenby by an author whose doctoral work assessed Allenby's predecessor as commander in Egypt and Palestine, General Sir Archibald Murray.

Perret, Bryan. Megiddo 1918, Lawrence, Allenby and the March on Damascus. London: Praeger, 2004. [ISBN: 9780275982928]

Covers the final collapse of the Turkish armies in Palestine and Allenby's coordination of his operations with Hashemite Arab forces and then the combined capture of Damascus.

Sheffy, Yigal. British Military Intelligence in the Palestine Campaign, 1914-1918. London: Frank Cass, 1998. [ISBN: 9780714646770]

A scholarly specialist text examining the subfield of intelligence and Britain's use of military intelligence against the Turkish enemy in Sinai and Palestine. Rich on detail.

\section{The Imperial Perspective}

Allenby's Egyptian Expeditionary Force was a remarkable multi-national, multi-cultural army, with men serving from across the British Empire, with Bou 2009 being the most recent author to cover Australia's part in the war. France and Italy also sent troops to join Allenby. Gammage 1974, Hill 1978, and Brugger 1980 are classic texts on the imperial perspective to the war. The story of the Indian troops that served with Allenby has not been told fully although Kitchen 2014 looks at it alongside the wider experiences of Australian and New Zealand forces.

Bou, Jean. Light Horse: A History of Australia's Mounted Arm. Cambridge, UK: Cambridge University Press, 2009. [ISBN: 9780521197083]

The latest word on the mobile operations of the Australian mounted infantry that formed the core to Allenby's mobile Desert Mounted Corps, based on wide-ranging primary sources by an author in command of his subject. 
Briscoe-Moore, A. The Mounted Rifleman in Sinai and Palestine: The Story of New Zealand's Crusaders. Auckland, New Zealand: Whitcombe and Tombs, 1920.

A celebratory contemporary account of the smaller New Zealand mounted infantry force that served with Allenby in Palestine.

Brugger, Suzanne. Australians and Egypt, 1914-1919. Melbourne, Australia: Melbourne

University Press, 1980. [ISBN: 9780522841756]

An interesting analysis of the experience of Australian troops in Egypt over the course of the First World War, including study of the often violent encounters between Australians based in Egypt and local people in cities such as Cairo.

Gammage, Bill. The Broken Years: Australian Soldiers in the Great War. Canberra, Australia: Australian National University Press, 1974. [ISBN: 9780708102381]

The classic text on Australia's involvement in the First World War, now dated but still worth reading.

Grey, Jeffrey. The War with the Ottoman Empire. Vol. 2. The Centenary History of Australia and the Great War. Victoria, Australia: Oxford University Press, 2015. [ISBN: 9780195576764]

This is the latest word on Australia's part in the war against the Ottomans on all fronts in the Middle East, including Allenby's Palestine campaign.

Hill, A. J. Chauvel of the Light Horse: A Biography of General Sir Harry Chauvel. Victoria, Australia: Melbourne University Press, 1978.

A useful book on the Australian commander of the Desert Mounted Corps under Allenby's command, insightful on how mounted troops were used in Palestine under Allenby's leadership.

Kitchen, James. The British Imperial Army in the Middle East: Morale and Military Identity in the Sinai and Palestine Campaigns, 1916-1918. London: Bloomsbury, 2014. [ISBN: 9781472505279]

A readable examination of the experiences of Imperial units of the British army in the Sinai and Palestine campaign. Using a wide range of sources, this work examines the combat experiences of Imperial troops and their reactions to service abroad. A work of great value to anyone interested in Britain's Imperial troops.

\section{Lawrence and the Hashemites}

There is a vast literature on the formation of the modern Middle East and on T. E. Lawrence, too, too extensive to cite here, but Wilson 1990 is the main text on Lawrence, with Lawrence's own account (Lawrence 1935) and James 1990 useful additions. All the works detailed here shed light directly on Allenby's role with the allied Hashemite Arabs, with Fromkin 1989 providing general coverage of the whole region. Allenby emerges from the war as a military man who wanted to maximize the military benefits of the Arab revolt against the Turks on his eastern flank. He accommodated British political-imperial needssuch as allowing the Hashemites into Damascus first on 1 October 1918, as discussed in Kedourie 1984 and Hughes 2005, to give the impression that they had liberated the city and so could establish political control- but he kept his eye firmly on the military prize of the destruction of all three Turkish armies in Palestine and Transjordan.

Fromkin, David. A Peace to End all Peace: Creating the Modern Middle East, 1914-1922. London: Deutsch, 1989. [ISBN: 9780233983936]

This is a general text, only parts of which cover Allenby's part in the postwar Middle East peace settlement, and a good introduction to a complex set of talks and decisions made just after the war, ones that formed the political structures of the modern Middle East.

Garnett, David, ed. The Letters of T. E. Lawrence of Arabia. London: Jonathan Cape, 1938. An early collection of Lawrence's letters and papers, a few of which mention Allenby. More generally, a useful introduction to Lawrence by way of his own writings. 
Hughes, Matthew. "Elie Kedourie and the Capture of Damascus, 1 October 1918: A Reassessment." War and Society 23.1 (May 2005): 87-106.

Hughes assesses the claims made by Kedourie 1984 that the British manipulated their operations to capture Damascus at the war's end to give the impression that the Hashemites got into the city first. He argues in favor of Kedourie's thesis, pointing to the political forces driving military operations that would continue after the war in the negotiations on the future status of captured territory.

James, Lawrence. The Golden Warrior: The Life and Legend of Lawrence of Arabia. London: Weidenfeld and Nicolson, 1990. [ISBN: 9781557785794]

James, who also wrote a biography of Allenby (James 1993, cited under *Biographical Accounts*), provides here a readable, concise account of the complicated life of Lawrence of Arabia.

Kedourie, Elie. "The Capture of Damascus, 1 October 1918." In The Chatham House Version and Other Middle Eastern Studies. Edited by E. Kedourie, 33-51. Hannover, NH: New England University Press, 1984. [ISBN: 9780874513042]

Using evidence from Australian Light Horse unit war diaries, Kedourie argues that the British high command ordered advancing British-led troops to skirt around Damascus and that they should facilitate the entry into Damascus of Hashemite Arab forces and their liaison officer, T. E. Lawrence. First published in Middle Eastern Studies 1.1 (1964): 6683.

Lawrence, T. E. Seven Pillars of Wisdom. London: Jonathan Cape, 1935.

Originally published in a very limited subscriber's edition in 1926, Lawrence's colorful, flowery account of his time with Hashemite troops during the Arab revolt was published for the wider public in 1935. It is a work of fiction as much as a work of history, insightful and interesting in its own way. Lawrence mentions Allenby in the book.

Wilson, Jeremy. Lawrence of Arabia: The Authorised Biography. New York: Atheneum, 1990. [ISBN: 9780689119347]

The definitive, magisterial official biography of Lawrence that also assesses Allenby's relationship to Lawrence and in great detail examines the Arab revolt and its relationship to wider military operations, and Lawrence's part in the First World War.

\section{Egypt}

Wavell 1943 (cited under *Biographical Accounts*) examines Allenby's period as high commissioner in Egypt (1919-1925) in the second part of his biography. The rising power of Egyptian nationalism has attracted a wide range of studies such as Long 2005 and Darwin 1981, most of which focus on the Egyptian side of events and not Allenby. The works cited here examine the challenges faced by Allenby as he negotiated with Egyptian nationalists - a subject covered broadly by Daly 1998 - over the terms of independence, achieved in some measure in 1922. Allenby retired in 1925, eventually to Wetherby Gardens in Kensington, dying in 1936.

Daly, W. M., ed. The Cambridge History of Egypt. Vol. 2. Cambridge, UK: Cambridge University Press, 1998. [ISBN: 9780521633130]

The Cambridge history provides an excellent summary of the key issues within Egypt that drove forward the Egyptian independence movement and with which Allenby had to contend.

Darwin, John. Britain, Egypt and the Middle East: Imperial Policy in the Aftermath of the War, 1918-22. Basingstoke, UK: Palgrave-Macmillan, 1981.

A classic text that examines the roots of British policy toward Egypt after the First World War in the context of the Egyptian revolt of 1919.

Elgood, P. G. Egypt and the Army. London: Oxford University Press, 1924. 
Elgood's dated work examines the place of the British army in Egypt, an occupying force in the country since 1882 .

Long, C. W. R. British Pro-Consuls in Egypt 1914-1929: The Challenge of Nationalism. London: Routledge, 2005. [ISBN: 9780415350334]

This study dissects the relationship between British power in Egypt and the rising tide of Egyptian nationalism that would continue until the final ending of British influence in Egypt in 1956. 